\title{
Tafilalt in the Mzab Valley - Algeria. A sustainable urban project in arid environment
}

\author{
Tafilalt no vale do Mzab - Argélia. Um projeto urbano sustentável em meio \\ ambiente árido
}

Abderrahmane Diafat[a], Said Madani[a] (1)

[a] Universite Ferhat Abbas Setif 1, Sétif, Algeria

How to cite: Diafat, A., \& Madani, S. (2019). Tafilalt in the Mzab Valley - Algeria. A sustainable urban project in arid environment. urbe. Revista Brasileira de Gestão Urbana, 11, e20190023. https://doi.org/10.1590/21753369.011.e20190023

\begin{abstract}
This paper aims to display a promising experience of designing a new community project based on the Mozabit old traditions to found their Ksour (plural of Ksar). The faith and "self-reliance" as ancient customs of the Mozabit society have led the Oases to survive in a hostile Saharan environment. Tafilalt project aims to respect the traditional architecture and values while creating architecture worthy of the sustainable development. The community in Bani Isguen city initiated the project in 1997, planning to create a new neighborhood for Bani Isguen ksar in order to alleviate the housing shortage in the Mzab Valley. The self-help, solidarity and collective work of this community allow low-income households to have access to affordable housing. The methodical approach fulfills a thorough analysis of the different steps concerning the process from the definition to the construction of such a collective project. This quite successful designed project tends to enhance the local urban environment and empower the community ties. A set of guidelines and recommendations are made in order to improve the design process and urban strategies of any alike coming projects.
\end{abstract}

Keywords: Heritage. Tafilalt Project. Community. Strategies. Design.

\section{Resumo}

O objetivo deste artigo é apresentar uma experiência promissora de criação de um novo projeto comunitário baseado nas antigas tradições mozabitas para fundar seus Ksour. A fé e a "autoconfiança" como costumes antigos da sociedade Mozabita levaram os Oásis a sobreviver em um ambiente hostil do Saara. O projeto Tafilalt visa respeitar a arquitetura e os valores tradicionais, criando uma arquitetura digna do desenvolvimento sustentável. A comunidade na cidade de Bani Isguen iniciou o projeto em 1997, planejando criar um novo bairro para Bani Isguen ksar, a fim de aliviar a escassez de moradias no Vale do Mzab. A autoajuda, a solidariedade e também o trabalho coletivo desta comunidade permitem que as famílias de baixa renda tenham acesso a moradias populares. A abordagem metodológica baseia-se na análise das diferentes etapas do processo, desde a definição do projeto até a construção desse projeto coletivo. Este projeto bem-sucedido foi projetado para melhorar o ambiente urbano local e fortalecer os 
laços comunitários. Um conjunto de diretrizes e recomendações será feito a fim de melhorar o processo de design e as estratégias urbanas de projetos similares.

Palavras-chave: Patrimônio. Projeto Tafilalt. Comunidade. Estratégias. Projeto.

\section{Introduction}

Stimulating the participation and involvement of local population is a central dimension and the necessary condition for success of any urban project. Experimentation with different instruments and tools enables the progress of a participatory management methodology of promoting local cultural heritage. Implementation of the project is viable when the result of debate and collective decision-making can spread ownership of the common heritage. It is through active involvement in the debates and various activities that local population is aware of the development potential embedded in local heritage of its own city.

Facing the site constraining conditions, the Mozabits constantly established their habitat while respecting their cultural references. The living natural environment combined to dominant and enlightening elements are used as starting points guiding this secular process. Through its long history, this community never ceased to maintain its identity embedded in the architectural and urban typology, climate, site and social structure. It is known that the faith and "self-reliance" are ancient customs of the Mozabit society, these secular customs have led the Oases to survive in a hostile Saharan environment.

Few positive experiences with improved housing areas in Algeria could be remarkable cases to study, like the Tafilalt project in the Mzab Valley, offering better environmental conditions in the Algerian contemporary history. The Mzab Valley is a pentapolis, composed of five towns, including Ghardaia. This pentapolis is $600 \mathrm{~km}$ south of Algiers and located in the Saharan Desert. It has been awarded national heritage in 1971 and world heritage by UNESCO in 1982.

Through such a first experience, the autonomous Mozabit community relies partly on the public subsidy related to a public action called "la formule Ghardaia" (Ghardaia formula).

The Tafilalt project aims to respect the traditional architecture and values while creating architecture worthy of a sustainable development. In 1997, the community of Bani Isguen planned the new project as an extension to the old Ksar in order to satisfy the housing demand in the Mzab Valley. The self-help and solidarity, but also collective work of this community, could provide a great opportunity of access to affordable housing for the low-income households.

The newly erected Ksar carried out on matching the millenary tradition with the requirements of today's life. The architectural components underlying this product reflect the old Mzab spirit. This community took the most of its heritage. The ancestral tradition, behind the constitution of a very particular built environment, is still powerful.

The approach follows a methodical analysis through an investigation concerning the different steps within the process from project definition to construction of this collective project. This quite successful designed project tends to enhance the local urban environment and empower the community ties. Some guidelines and recommendations are made in order to improve the design process and urban strategies of any alike coming projects.

\section{Background}

A traditional human habitat, with a distinguished vernacular architecture in the Mzab Valley, created during the 10th century by the Ibadits, has been preserved intact until nowadays. An opposite way to other civilizations, the Mozabits have had the idea to look for a hostile and unwelcoming area of the Saharan desert. In fact, the scarcity of water, as a primary factor, was the basis of choosing this site where they created five oases towns, known since then as the Mzab valley (Riphenburg, 2006) 
The spatial quality of this networked 'Pentapolis' provides sustainable urban environment. Although, the UNESCO has considered Ghardaia as an important monument of mankind for conservation due to its planning (Cataldi et al., 1996). The determinant factors in such hostile environment, like the permanent aesthetic values of these architectural and urban spaces, would help in designing new housing projects.

The Ibadits allowed the site to reach an urban dimension, leaving the present heritage simple, useful and completely integrated to the environment. The Mzab architecture matches the Mozabit community's way of life with regard to the family structure. In three and a half centuries, from the eleventh to the fourteenth centuries, the urbanization process of the valley has led to the creation of five ksour (plural of Ksar): El-Atteuf (1012), this first city has inspired many architects, such as Le Corbusier, Bounoura (1046), Ghardaia (1048), Bani Isguen (1347) and Melika (1350). Each ksar has its own palm grove, a system of irrigation, cemeteries and so on.

The French occupied the northern part of Algeria in 1830, and the Mzab in 1882, the colonial action in the Sahara came later with more caution and respect to the existing fabrics than the occupation of historic cities in the Northern part of the country (Babanedjar, 2008).

After Independence in 1962, Ghardaia (Figure 1) maintained its administrative status as a Commune (Muncipality), and then following the administrative division of 1974, it stepped to the status of Daïra attached to the Wilaya of Laghouat. Finally, in 1983, it was promoted to the rank of Wilaya.

These experienced three decades of socialist management, marked by major political and socio-economic changes, affected the city in its urban and architectural aspects. This system was carrying values incompatible with the very special Mozabit lifestyle and social organization. Following the adoption of the 1989 constitution, which opened the field to the market economy, good governance as well as participatory democracy, the State is no longer the only housing producer. It has instead become a partner, regulator and funder. Land and property transactions, which are also the citizens' responsibility, are subject to market conditions. In addition, it is possible to freely conduct the building act individually or collectively as an organization. This political openness has allowed the development of private real estate in the country (Adad \& Redjem, 2012).

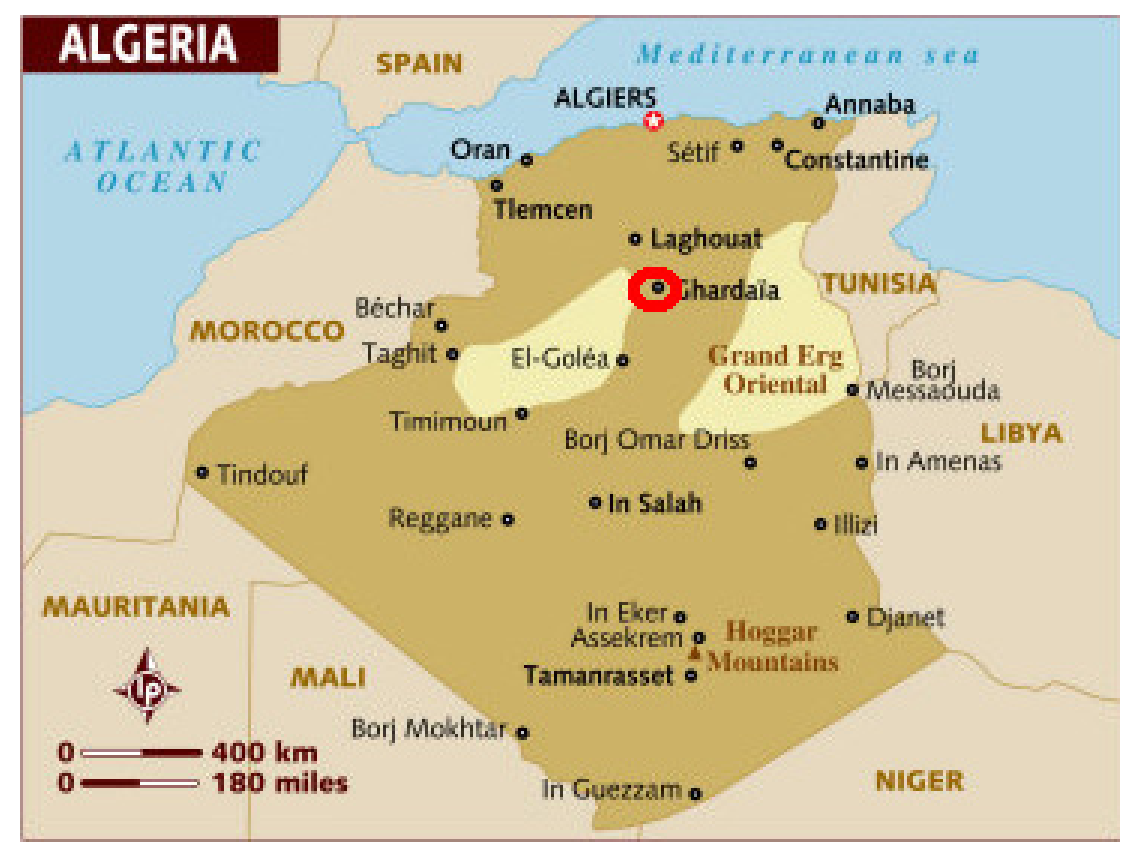

Figure 1 - Ghardaia localization. Source: NetPosterWorks (2013). 


\section{Theoretical framework}

\section{Sustainability}

The variety of literature study that much has been written about sustainability and sustainable development shows that the terms are used differently. First developed in the 1980s, they were from the beginning unclear and are open to interpretation and various meanings.

Different conflicts between all dimensions and aspects of sustainability have always existed, but as long as people are included in the process, social and environmental problems are addressed the system could in the end be sustainable (Koglin, 2009).

According to Radberg (1996), much of the great confusion in the fields of sustainability in urban planning stems from the fact that the theories are formulated on a very general and abstract level. There is a need for empirical facts, observations. Systematic descriptive classification of the urban structure on the micro-level is required in order to process the collected data on existing urban environments.

One of the most used and accepted definition emerged from the UN Report, Our Common Future: "Sustainable development is development that meets the needs of the present generation without compromising the ability of future generations to meet their own needs" (Wikisource, 1987, p. 54). This definition occupies a belief that communities can achieve economic development, environmental protection and desired quality of life for all its citizens ideally at the same time. Campbell (1996) conceptualizes sustainability in three 'E's. Environment, economy and equity have been referred as 'there E's' of sustainable development.

In recent years, the institutional dimension of sustainable development, also referred to as "democracy" or "governance", has increasingly been emphasized and included as a fourth pillar (Meadowcroft, 2000). This approach reveals the importance of institutional change for sustainable development, as stated in its operational definition, and as already internationally agreed on in 1992 in Agenda 21 where the institutional dimension is a separate chapter next to a socio-economic and environmental one.

In fact, in this century, there is a need for a new urban ethic, based on the concept of social sustainable development that integrates the notions of social equity, environmental sustainability, economic efficiency and social integration. Ultimately, to implement a sustainable strategy, it is necessary to involve the different actors in the process of making and managing the city.

The shift away from our traditional architecture and the standardization of built environments globally, due to the increasing globalization and advancement in science and technology, resulted in lack of cultural and regional identity. The use of same building methods, materials and styles globally, challenges our talent to achieve sustainable living required for the climate responsive architecture, which is obvious in current housing architecture (Gulzar, 2017).

The living values are the basis on which is built a society, and these are expressed through memory, rituals, festivals, traditions, referring to its culture. Sustainable development means to effect change in behavior, which leads to re-examine these standards and values. Culture is therefore the transformation basis of intervention modes upon the territories, in order to formulate sustainable development policies in line with the local expectations and aspirations. Sustainable development does not then refer to a single model, but mainly stems from local identities, aspirations and dynamics that make up the local culture. 


\section{Heritage and its role in development}

Heritage, as defined, is a factor of social stability, a sign of identification and belonging to a territory. It is meaningful and useful, noticeable by community ties; heritage is not a dead object, it is alive and holds some emotional charge that does not necessarily hold references or architectural aesthetics. The objective to worth the heritage reveals the importance of respecting the cultures and human activities that reflect past and present values through the use and activities of a society (Rouxel, 1999).

Any city carries the memory of a lost city: it connects us to the past, to the usage, to human historicity. Similarly, the architecture is a palimpsest: it never does "clean slate", it rewrites. This reactivation of the past serves as a springboard to the future and urban planning becomes a project logic articulated on the town's past, a past that broadens history museum or the mummified past. (Poncelet et al., 2005)

The "traditional" dwelling is a realm of multiple determinants. As the result of various types of interaction between the inhabitant and his environment, and between the different familial, political and religious elements which constitute society (Toffin, 1994).

In fact, the vernacular architecture, as a dynamic system able to adapt itself to continuous environmental changes, aims to protect the building's environment by the use of local materials to save energy and create better living space. It aims also, during design process, to enhance cultural aspect of buildings and the character and identity of place. Consequently, traditional architecture with its better-quality character and environmental awareness can be a good example of achieving both aspects environmental and cultural sustainability (Momtaz \& Feisal, 2012).

\section{Urban governance and legislation}

According to Anwar Shah (2008), a large and growing number of countries are encouraged by the information revolution and globalization to reconsider the roles of various levels of government and their partnership with the private sector as well as civil society. These reforms usually engage shifting responsibilities to local administrations and beyond government suppliers, with the purpose of strengthening local governance. A movement of this kind has generated a great awareness in learning from the history of nations as well as from present practices across countries on local government management. Hence, this paper provides a reflection on local governance to this interest in Algeria, in general, and in the Mzab region in particular.

The urban development increasingly relies on heritage that becomes the object of global strategies for city transformations. The historical knowledge of the built environment in a hostile and arid territory is then very necessary as a working tool for city designers.

Latest theoretical reforms to decentralize the management, gave more resources and power to local governments, yet their administrative, fiscal and political autonomy continue to be limited. Therefore, we should not see local governance reforms as a central government withdrawal, but rather as a tool for (semi-)authoritarian regimes in the MENA region to widen further government control (Bergh, 2010).

Herein, we intend by urban governance a declared or effective process of collective decision-making, corresponding to the overhaul of the framework decision. The use of governance permits to switch from hierarchical and vertical social relations to a horizontal and shared dialogue among multiple stakeholders.

Across its large urban dynamics during the Post-colonial era, Algeria is still facing challenges of urban management. The rapid demographic growth led to urban expansion through new allotments and collective housing areas, and recently through public and private estates development. However, the urban development was limited to new constructions and neglecting the preservation of existing buildings in the historic center. 
The housing demand and informal settlements in the fringe-belts made the issue of habitat a major concern. Since Independence in the 1960s, the existing housing stock had kept marginalized and excluded from the building sector, except the construction of public rural villages and some private selfbuilt houses.

A new legislation issued in the 1990s and the State had to stop being a provider of social needs, but a regulator within the entire economic environment. The social and economic issues come forward to a large appraisal, the land ownership is warranted and housing is not a social product: it becomes an economic product for rental or sale purposes. The state will provide subsidy according to the income and housing conditions, and so the private sector will have more shares in housing delivery (Madani \& Diafat, 2016).

It is now obvious in Algeria that "new aspirations are emerging and it becomes crucial to support this demand for change, from the depth of social body, and be so close to people's settlements. Furthermore, the local actors recommend that both representative and participatory democracy may be the basis of exhaustively inclusive democratic governance in local communities so that iteratively and considerably enhances democratic governance of the entire country (CNES, 2011).

The governance practices improvement, based on the expectations of local actors and all stakeholders of local development, should be based on coherent, cohesive, consensual measures around tasks aimed at:

- Coordination of local policies;

- the Creation of appropriate coordination surfaces with the sectors;

- Impulsion of principles related to equity, transparency and accountability;

- Strengthening the mutual confidence for the final service with a greater efficiency from the local public action (CNES, 2011).

Simultaneously, Future generations should be capable to include their contribution of creation and permanence to the Algerian heritage. From the village of Kabylie, Aures, Mzab and in harmony with the inherited city and the one we have built, there should be a continuation and continuity between generations. Filling the gap for the time being, and preventing the future generations from other breaks are the main objectives of the Algerian policy (Belayat, 1985).

The law concerning patrimony heritage and relative to the regional and town planning is the 90-29 of December 1, 1990. Its innovation is certainly the land use plan (P.O.S.) and the Master Plan (P.D.A.U.) that replaced the (P.U.D.). This law aims to edict general rules in order to organize urban land production, create and transform the built environment, the balance between the environment preservation and historic centers with cultural patrimony heritage, according to the urban and town planning national policy.

Therefore, the land use plan (P.O.S.) fixes in details the land use and construction rights. It indicates the quarters, streets, monuments and sites to be preserved, renewed and restored.

However, to implement these two plans some difficulties appeared for the following reasons:

- The gap between the time of elaboration and approval of instruments, and the deadline for the achievement of different urban dynamics;

- The used standardization approach is not valuably suitable for different geographical, economic and institutional states, and/or the difference in complexity levels between cities;

- The lack of coherent linking with land planning. 


\section{Methodology}

The analysis of theoretical issues concerning this heritage and the case study are developed; we conducted an empirical research work in order to collect information about this promising project in the Mzab Valley, an arid environment in Algeria.

This methodological approach involves a comprehensive analysis of the different steps of the whole process concerning this collective urban and architectural project from the definition to its construction.

The literature search and field survey were the main methods of collecting data: the literature search about the notion of sustainability, issues of heritage and urban governance led us to the Internet, libraries and documentation centers. The documents consulted concern thesis, articles and different reports of the Foundation. The explored literature highlights the relationship between heritage and architectural and urban design, the relationship between urban and sustainable development in general. Field investigations completed the information from literature search. The surveys we conducted between 2008 and 2018 used three techniques: observation, interview and questionnaire survey. The observation consisted mainly in travelling with teams of our students during our yearly field trips in the Mzab Valley. Our team observed the five main cities while analyzing the different mass and house plans. These visits allowed us to understand better the spatial dynamics of urban space and immerse ourselves in the behavior of the various actors involved in the economic life of these Ksour. We conducted interviews with the president of the Amidoul Foundation, Director of the OPVM (Office de la Protection de la Vallée du Mzab) and some notable Mozabits and citizens who benefited from these dwellings. Our discussions focused on their role in the implementation process concerning this major urban project, their post-occupancy evaluation related to indoor and outdoor spaces, the state of environment. The questionnaire survey targeted officials of the old ksar of Bani Isguen and traders who settled on the old ksar site. Our choice has its explanation in the fact that the subject is specifically interested in ksar of Bani Isguen. The reasoned choice reflects the empirical method used for surveys. However, the refusal of some actors did not allow interrogating all the approached people, five officials and fifteen merchants from Ksar of Bani Isguen accepted our investigation.

\section{Findings}

\section{The Mzab Valley sustainability and heritage}

The Mzab Valley is a universal heritage, classified by UNESCO in 1982 due to its ksourian urbanism (pyramidal) shaped oasis in an arid area. In addition, the Mzab is a southern region in Algeria where a population practicing Ibadit Muslim rite. This rite refers strictly to the holy Koran and the Sunna. Also, it is characterized by the tolerant appearance and the solidarity between Mozabits.

In this arid desert climate under extremely hot summers, the clear planning of these cities in the Mzab Valley, with a central dominant mosque and a sufficiently designed courtyard house, makes these human settlements among the most attractive ones in the Algerian desert. Each town has a permanent winter town and a summer town located in the nearby oases. The winter town is the main residence for most of the year. The summer town is used during the harshest period of the year when the population migrates to a milieu that is cooler and shaded by palms, a pattern that is still appropriated today. Overall, the town in this hostile environment looks like a compressed and condensed structure. (Meliouh \& Tabet, 2013)

Moreover, Ibadits of the Mzab Valley within a pyramidal social organization could adopt a number of social practices. Thus, a set of families regrouped in a big family, "Achira, the Achira are grouped to form 
an "Arch" and within the religious structure, called "Halqa Azaba" that guides spiritually, orients and advises the Ibadits.

The traditional Housing in the Mzab is defined by the following:

- Hierarchy of spaces;

- Human dimension;

- Quality of spatial composition.

In addition, the effort to integrate housing on sloping land gave a variety of architecture.

Designed for egalitarian community living, the architecture of housing in the Mzab valley gives more respect to the family privacy. Each house has an underground room and two upper levels, with a space in the center, transparent with a sky window. For the period of summer, Mozabits move around to their homes located in the palm grove oases, watered by devised irrigation elements or sharing water systems (Riphenburg, 2006).

Traditional Mozabit houses offer climatic arrangement suited to their climate. It is important to keep the example. There is a possibility to adapt them according to the "modern comfort" and construct 'modern buildings' that are inspired from the traditional houses (Ravereau, 2007).

The Mzab Valley has been classified as protected area. The protected zone concerns the entire valley with a total area of $54 \mathrm{~km}^{2}$. Following this classification, a permanent plan of safeguard and development of the safeguarded sector (P.P.S.M.V.S.S) has been launched.

The Office of Protection and Promotion of the Mzab Valley (OPVM) committed an ambitious program of restoration concerning historic monuments; such as religious and defensive buildings as well as water infrastructures. For the first time, with the civil society, "the Heritage Month" as a new tradition has been set from April 18th to May 18th of each year since 1995.

\section{The ksar of Bani Isguen}

The ksar of Bani Isguen, founded in 1347, is located on the southern side of the Mzab Valley and known as the holy city. This walled city, with only two gates, is the most conserved in the Mzab region. Streets are narrow (Figure 2) and some of its parts are forbidden to foreigners. Moreover, the market place of traditional crafts is scenic.

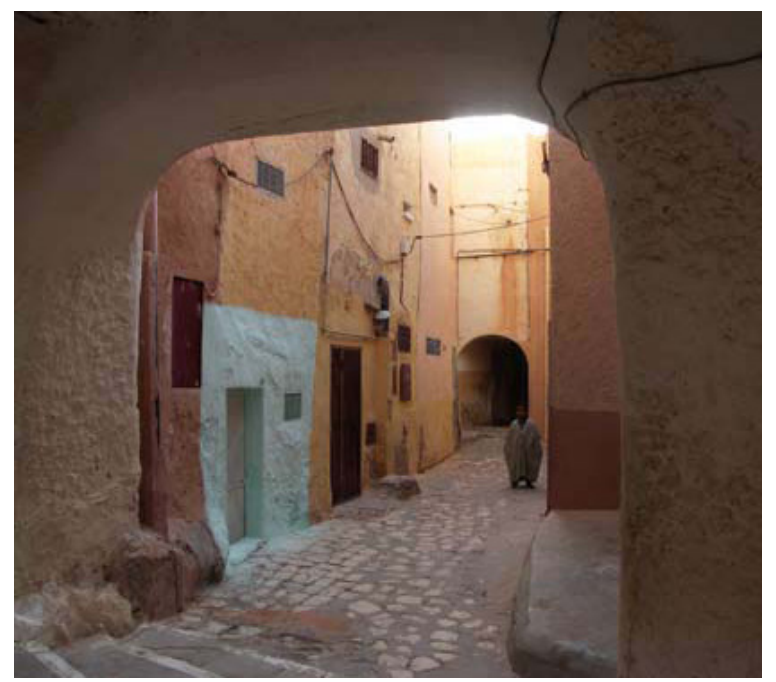

Figure 2 - A narrow street in the ksar of Bani Isguen. Source: Zouhir Ballalou (2008).

The city's Council of religious affairs (Halqa Azaba) is managed by twelve key men of the community. Twelve represents the same number of the men who took refuge in the valley almost 1,000 years ago. 
These men are: the imam, the muezzin, the teacher of the madrassa and the mahat, two treasurers and five men who are responsible for the funeral actions. The council of social affairs (Halqa Doman) incorporates a delegate of each group (Ashira) and deals with the mundane affairs of a community (Riphenburg, 2006).

In Bani Isguen (Figure 3), the oldest Ashira settled at the highest point in the city, near the watchtower, it comes from a Berber family from Tafilalt.

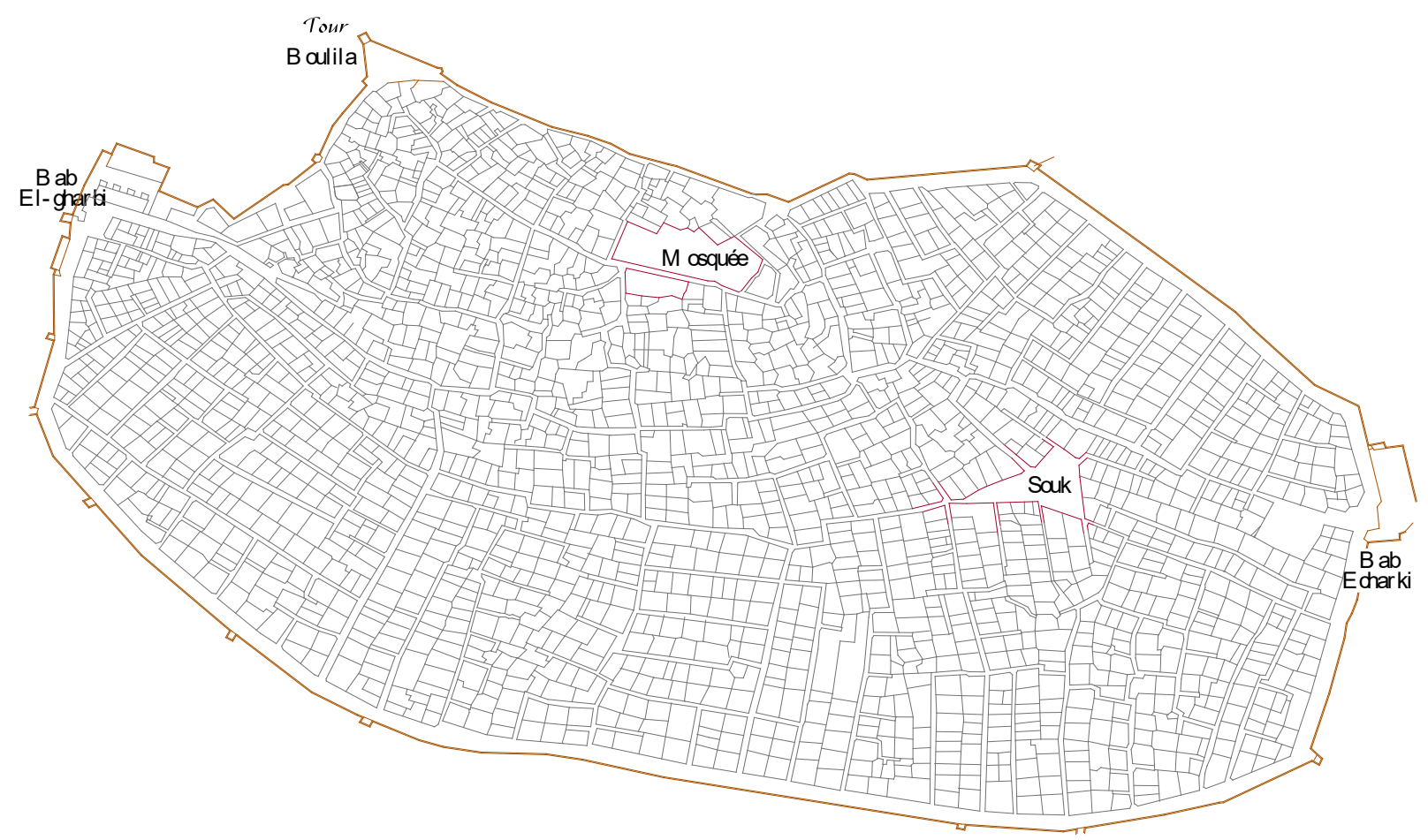

Figure 3 - Bani Isguen plan. Source: Mashary (2003).

\section{Governance in the new ksar Tafilalt}

The new ksar came to answer the question: how to meet housing demand of the middle class at the ksar of Bani Isguen? An approach that integrates the economic context, social cohesion and heritage aspects of the site.

This social non-profit project is launched by the Amidoul Foundation, which is chaired by Mr. Ahmed Nouh, Doctor of Pharmacy. Initiated in 1997, the project was created on a rocky hill in the Mzab Valley. Tafilalt is indeed a new ksar overlooking the holy Bani Isguen.

The new ksar has a social and ecological purpose. The project aims to take benefit from the ancient customs based on faith and "self-reliance" which allowed these oases to survive in an unfriendly Saharan environment and create an architectural heritage worthy of sustainable development. The project approach combines equally the practices, values of cohesion, shared aid and social standards with the claims of contemporary living comfort (Madani \& Diafat, 2010). 


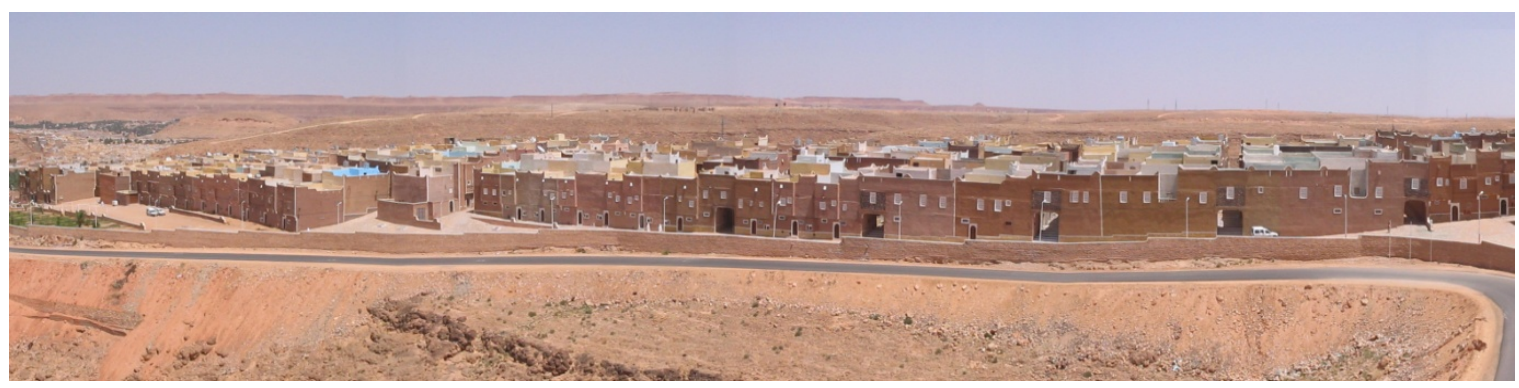

Figure 4 - Approach view to the new ksar Tafilalt. Source: Authors (2016).

Table 1 - Project data

\begin{tabular}{ccc}
\hline 1 & Project name & The new ksar of " Tafilalt " \\
\hline 2 & Sponsor & Amidoul (Estate Civil Society) \\
3 & Global Land Area & 22.5 ha \\
4 & Residential area & $79670 \mathrm{~m}^{2}$ \\
5 & Number of unit & 870 homes \\
6 & Location & Bani-Isguen, Ghardaia, Algeria \\
7 & Natural Site & Rocky land with a slope: 12 to 15\% \\
8 & Climate & Saharan \\
9 & Starting date & March 15, 1997 \\
\hline
\end{tabular}

Source: Amidoul Fondation (2016).

\section{Principles and references}

The objective of this urban experience is to achieve a sustainable development in the Mzab valley. The used method in this project ranges from interpreting to reading the ksar through its past in practical objective, not only limited to the technical aspects in this sustainable development approach, so that it takes into consideration cultural and symbolic aspects of the city.

The "Tafilalt new ksar" project (Table 1) is a very special human experience with its social, urban and ecological approaches (Figure 4). It is based on:

- Contribution of traditional social institutions;

- Proposal of a rational environment of the building using the standards and requirements of the contemporary housing comfort, while leading the research work of bioclimatic architecture;

- Involvement of the inhabitant in the implementation process of his home, in its cultural dimension, practices and values of social cohesion and self-reliance;

- Aware interpretation of the sustainable concepts related to this millennium architectural heritage;

- The imperative site choice in a rocky environment in order to preserve the weak environment.

The chosen urbanization mode is appropriate to the Saharan environment, namely the ksourian typology defined by the following characteristics:

- Compact fabric;

- Organizational structure of public spaces;

- Respect for the human scale;

- Respect for the identity of the city by the analytical elements, such as: urban gates - souk transition spaces - public spaces (Figure 5);

- Existing elements of high symbolic value: well, minaret, tower. 


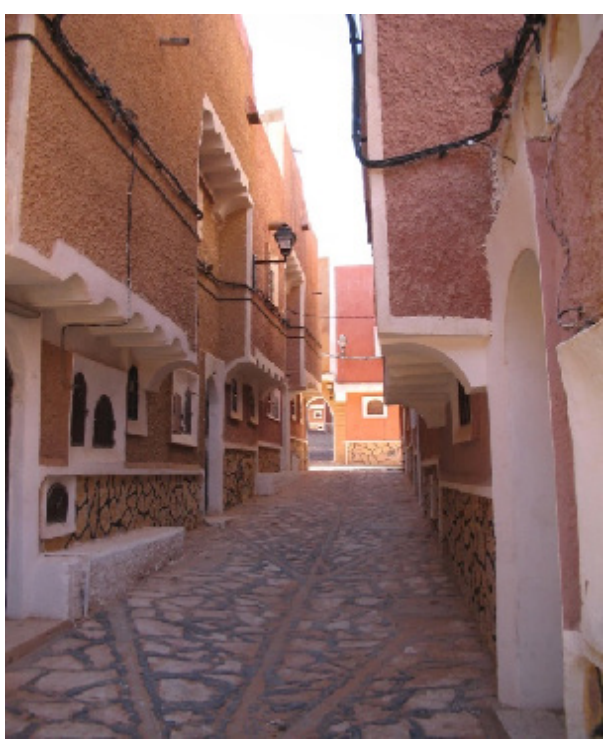

Figure 5 - Narrow street with shade in Tafilalt. Source: Amidoul Fondation (2016).

The project has gradually evolved into an urban complex. There are blocs with plots, covered walkways and pathways in different widths giving hierarchy to urban space. This new ksar has integrated also within its walls a series of appendices and economic, social and cultural structures such as libraries, schools, shops, community house.

A type of beneficiary has been adopted as a reference: the middle class and some lower income. A social commission has been established to select the beneficiaries after the traditional commissions' approval.

Table 2 - The project actors: role and structure

\begin{tabular}{|c|c|c|}
\hline Actors & Composition / structure & Role \\
\hline Social Commission & $\begin{array}{c}06 \text { members selected by the council of notables. } \\
\text { The commission Works on a voluntary }\end{array}$ & $\begin{array}{l}\text { Select beneficiaries according } \\
\text { to the studied criteria }\end{array}$ \\
\hline $\begin{array}{l}\text { Real estate company } \\
\text { Amidoul }\end{array}$ & $\begin{array}{c}\text { Technical and Commercial Branch } \\
\text { The Manager } \\
\text { (Architect + } 02 \text { Engineers + Financial advisor + } \\
\text { Accountant) } \\
\text { Technical Officer (T.O.) Number } 04 \\
\text { Every Technical Officer is in charge of } 04 \text { teams } \\
\text { The team is composed of: } 01 \text { craftsman + } 02 \text { workers } \\
05 \text { workshops were created: } \\
1 \text { - Plaster workshop } 2 \text { - Wood joinery workshop } \\
3 \text { - Beams workshop } 4 \text { - Hollow workshop } \\
5 \text { - Metal joinery workshop }\end{array}$ & $\begin{array}{l}\text { Build different houses and } \\
\text { facilities } \\
\text { - Control the costs } \\
\text { - Reduce time } \\
\text { - Quality }\end{array}$ \\
\hline $\begin{array}{l}\text { The } 02 \text { associations } \\
\text { of the city: } \\
\text { - El Amel } \\
\text { - Tadhamon }\end{array}$ & $\begin{array}{l}\text { The officers + all beneficiaries (group work) } \\
\text { Volunteer work: on weekends and holiday periods, } \\
\text { (participation of adults / children / women) }\end{array}$ & $\begin{array}{l}\text { Mobilize individual and financial } \\
\text { resources to improving the } \\
\text { quality of life in the city }\end{array}$ \\
\hline
\end{tabular}

Source: The authors (2016).

\section{Housing program}

According to the chair Dr. Nouh, the Tafilalt project is a fact of activism and concrete actions for the society. The main goal is to make housing accessible to everyone. However, the foundation does not want to see grow in the valley dormitory or ghettoes as in the northern part of the country. The traditional Mzab house has been the source of inspiration in this project. 
The dwellings are introverted types with a spatial distribution similar to the traditional house within a contemporary comfort quality.

The element "courtyard" is introduced to increase the lighting and ventilation of the house and expansion of its indoor spaces. However the hierarchy of spaces is maintained, the use of local materials such as stone, plaster and lime, in addition to the narrow alleys to break the wind of sand in order to make it really matters of the "Ksar's spirit."

The project phased process allowed a continuous evaluation of architectural choices and improved used techniques. The housing program is composed of two floors with a summer terrace spread over three (03) levels:

- First level: kitchen, Parent bedroom, Family sojourn/living room (tizefri), Court - Wast Eddar (central hall) - toilet;

- Second level: Rooms for Children, toilet, Wast Eddar (central hall);

- Third level: Laundry or utility room - summer terrace.

The housing units are composed of two levels: summer terrace spread over three (03) design alternatives/ Variants.

\section{Financial aspects}

For the Mozabits any form of action intended to benefit or promote the good of other persons must be done in a total discretion. For religious reasons, the finance issue is approached with great delicacy. The status of the dwelling is unknown, the economic importance of the dwelling is an issue for which it is difficult to obtain clear and exact information (Donnadieu \& Didillon, 1977). Whatever, it must be underlined that the ancient ksour were the community only achievement without any external contribution. On the other hand, those of today are the result of the combined citizens and public funds (Adad \& Redjem, 2012).

Various workshops for handicraft production were created to minimize the construction costs: staff and plastering, units of cutting stone, metal and traditional joinery (from the palm trunk), etc (Table 2).The project has developed a financial procedure (Table 3) and incorporated the state subsidy of 500,000 DA (Dinars). The amount to be paid by the beneficiary is spread on four parts in order to facilitate the payment (Figure 6):

- $\quad 1 / 4$ at the reservation contract;

- $\quad 1 / 4$ at the end of major works;

- $\quad 1 / 4$ while getting the keys;

- $\quad 1 / 4$ will be staggered according to the purchaser's income.

Table 3 - Cost \& Number of units

\begin{tabular}{|c|c|c|c|}
\hline Area & $50 \mathrm{~m}^{2}$ & $90 \mathrm{~m}^{2}$ & $130 \mathrm{~m}^{2}$ \\
\hline Number of unit & 250 & 550 & 70 \\
\hline $\begin{array}{c}\text { Housing cost } \\
\text { Algerian Dinar (DA) }\end{array}$ & 1000000 & 1400000 & 1900000 \\
\hline
\end{tabular}

Source: Amidoul Fondation (2016).

The Real Estate Company Amidoul intervenes to help, in cases where beneficiaries were unable to pay especially the first part ( $25 \%$ of the total sum) or other parts. 


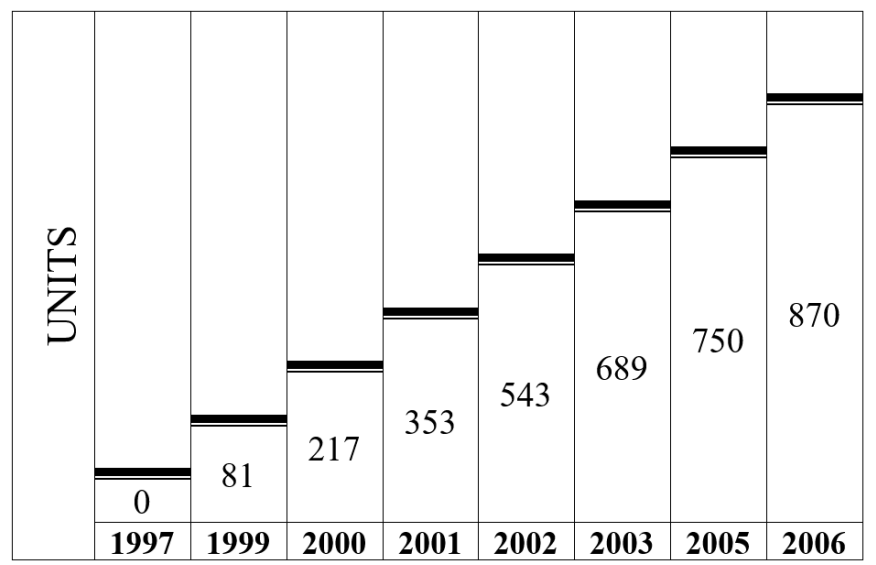

Figure 6 - Housing units delivery deadlines. Source: Amidoul Fondation (2016).

\section{Discussion}

The aim of our research was to display a promising experience of designing a new community project based on the Mozabit old traditions to found their Ksour (plural of Ksar).

Our article first substantive achievement is the detailed discussion on the treatment of the word "sustainability". Many definitions of the word sustainability reviewed in the literature provided a ground to serve as the overarching concept of the theoretical framework. Issues of heritage and urban governance were also investigated and incorporated as secondary components.

Based on the knowledge from the scientific literature, the findings from the case study provide meaningful facts.

Ksar Tafilalt is a unique experience built by local means and expertise for local use. It is a social, economic and environmental success, one of the most typical achievements in Algeria.

Lastly, investigations with the Amidoul foundation's president, confirmed that both studio apartments and villas in Tafilalt were built at a cost "three times cheaper than the country average".

The initiative aims to restore some ancestral customs based on faith and "self-reliance" of every citizen who lives in this new city. This unique Ksar combines architecture and sustainable development with an approach that makes it possible to survive in a hostile environment.

This experience with its main strengths aims to act in response to a very strong social demand thus contributing effectively to shorten the housing crisis for Bani Isguen inhabitants, including the middle class and poor people, and preserve Bani Isguen palm grove from the spread of new construction.

While Taking into account the current economic environment and public aid, it is improving social cohesion and ancient practices; program collective activities for the site to help creating a social environment that exists in the old ksar. Periodic social activities are maintained throughout the year.

Also, it tried to conciliate practices and values of cohesion and social aid related to the contemporary comfort requirements with a design of this new ksar that responds to the Saharan environment by bioclimatic comfort; the proposed elements create a bioclimatic microenvironment with shading circulation paths, protection against sandstorms and dissemination of green space.

For some inhabitants this experience improved the status of the traditional Mozabit habitat, the architecture of this new ksar tends to re-interpret the model of traditional urban house by adding new spaces, such as the courtyard and the office, in addition to spaces for arrangements due to the constraints of the relief (Messahel, 2011).

Concerning urban form, it respects the heritage aspect of the site. Inspired from the local 'Mzab' style, architecture of the new ksar is based on compact and high-density construction and respect of the heritage values, and the use of local building materials in the construction process. In addition, this 
successful urban project integrates, in the design process, the urban and architectural heritage, which responds to the inhabitants' needs. (Madani \& Diafat, 2010).

Despite these main strengths, there are some weaknesses with the project that could be summarized in the following few sentences:

Construction of the ksour is not a continuous ancestral process of urbanization in the Mzab Valley.

We noticed the failure to observe the principles of traditional urbanization in a ksar-oases system (the new ksar does not have palm grove), thus the inhabitants remain attached to the mother palm grove. Moreover, an urbanization process of natural land on the edges of the valley contributes to the disappearance of the balanced landscape established between the five ksour; palm grove and natural site. The southeast orientation has even not been followed to benefit from the sun in winter and get protection from cold winds.

\section{Conclusion}

The singularity of this experience lies in the approach that has been implemented; the inhabitants conducted mainly by themselves this project during weekends and holidays. Yet, the association president, a civil engineer, was in charge of the site management and external relations as well as technical aspects of buildings with the assistance of some permanent masons (Adad, 2008).

The Touiza and self-reliance acts represent ancestral values for the Mzab Valley inhabitants. The alliance of these acts with the state contribution made the Tafilalt project becoming reality. The undertaken reinterpretation of planning and architectural principles of the traditional houses in the Mzab region, gave a real meaning to the concept of governance by drawing together the traditional social institutions and involvement of the future users in defining spaces of their future homes.

In fact, the user's involvement in the creation process of his neighborhood is the finest motivation for him to take care of his dwelling. It is true that living the entire building process of the home makes it a part of your memory and this is part of sustainability. Tafilalt project is becoming already a destination for national and international tourists and started to contribute to the economy of the whole valley.

Any successful urban development strategy should be based on public and private investment in the old cities. The process of such a successful experience relies on mobilizing and integrating local expertise, from the Mozabit society, and this way of leading the housing process improves local governance and stakeholders' involvement.

Despite this fact, the country still shows evidence of weak notion and lack of transparent and accountable local governance, in addition to the lack of effective local civil associations that could evidently act as "countervailing powers" vis-à-vis local governments.

In fine, the absence of decoration in the architecture of old urban fabrics expresses the puritanical rigor of the Ibadit rite. While the typo-morphology and built environment of the new ksar Tafilalt are inspired by the traditional urban environment model (height, hierarchy of outdoor spaces, prospects, types of openings, textures, colors etc.), the construction of this ksar is significant because it is a natural, cultural and chronological extension of the ksours and it also illustrates the contemporary version of local know-how. The Ibadits reject urban production because of the so-called "modern" process; they have combined new techniques and old know-how to create architectural products suited to their social practices. Tafilalt is the place where they sought a conciliation between tradition and modernity. It is a conscious process of healing in local urban history, a new ksar of traditional inspiration at the same time with the rhythm of the technical innovations. In other words, it is a reinterpretation of the architectural and urban language of traditional ksour in arid environment.

- This experience of participatory and self-help housing, built efficiently with local materials and technologies, is accessible to people and much more affordable, practical and advantageous for many municipalities that have housing shortage; 
- Public Authorities could use this operational mode to set up an independent consultancy service in the various municipalities to generate this participative housing process;

- The tradition of participation in the planning and building process is a precious lesson for contemporary constructions. The Ksar Tafilalt experience can be generalized throughout the country because the good will, sacrifice spirit and social help exist everywhere.

\section{Acknowledgements}

The authors acknowledge the financial support received from the Laboratoire PUViT, Université F. A. Sétif 1 , Algeria, for its support and encouragement in carrying out this research work.

\section{References}

Adad, M. C. (2008). Participation de la population à son habitat: cas d'un nouveau ksar au M'zab. Revue des Science et Technologie D, 28, 67-76.

Adad, M. C., \& Redjem, A. (2012). Production de l'habitat dans les nouveaux ksour, symbiose entre intervention de l'Etat et action Communautaire: cas du Ksar Tafilalt dans la vallée du M'zab. Revue Perspectives \& Sociétés, 3(2), 124-148. Retrieved in 2019, January 28, from https://www.academia.edu/28517226/Production_de_lhabitat_dans_les_nouveaux_ksour_symbiose_entre_interve ntion

Amidoul Fondation. (2016). The Amidoul Foundation for the promotion of ecological habitat in Ghardaïa Retrieved in 2019, January 22, from http://tafilelt.com/site/

Babanedjar, Y. (2008). Principes et règles de la fondation et du développement des Ksour de la vallée du M'Zab: une pertinence toujours d'actualité. Grenoble: Mémoire de DSA- National Superior School of Architecture.

Ballalou, Z. (2008). Revitalisation urbaine pour la sauvegarde du patrimoine, cas de la vallée du M'Zab. Retrieved in 2019, January 22, from http://openarchive.icomos.org/1401/9/zouhir\%20ballalou.pdf

Belayat, A. (1985). Discours d'ouverture. In Actes du Colloque Algéro-Français: 'Les politiques urbaines'. Algérie: Ministre de l'Habitat, de l'Urbanisme et de la Construction.

Bergh, S. I. (2010). Decentralization and local governance in the MENA region (Economy and Territory/Territory and Transport, pp. 253-258). Barcelona: IEMed. Retrieved in 2019, January 22, from https://www.iemed.org/anuari/2010/aarticles/Bergh_decentralisation_en.pdf

Campbell, S. (1996). Green cities, growing cities, just cities? Urban planning and the contradictions of sustainable development. Journal of the American Planning Association, 62(3), 3296-3312. http://dx.doi.org/10.1080/01944369608975696.

Cataldi, G., Abdelhamid, R., \& Selva, F. (1996). The town of Ghardaia in M'zab, Algeria: between tradition and modernity. Traditional Dwellings and Settlements Review, 7(2), 63-74. Retrieved in 2019, January 28, from http://iaste.berkeley.edu/pdfs/07.2f-Spr96Cataldi-Abdelhamid-Selva-sml.pdf

Conseil Économique et Social National - CNES. (2011, 29-30 decembre). Dialogue national autour de la définition d'objectifs pour un meilleur développement local. Dans 50 recommandations pour soutenir une nouvelle dynamique dédiée aux attentes et aux ambitions des citoyens. Alger: CNES. Retrieved in January 22, 2019, from http://www.cnes.dz/cnes/wp-content/uploads/2011/12/50-recommandations.pdf

Donnadieu, P., \& Didillon, H. J. M. (1977). Habiter le désert, les Maisons mozabites (pp. 147). Bruxelles: Editions Mardaga.

Gulzar, S. (2017). Traditional dwellings: an architectural anthropological study from the walled city of lahore. Journal of Advances in Agricultural \& Environmental Engineering, 4(1), 152-158. 
Koglin, T. (2009). Sustainable development in general and urban context: a literature review (Bulletin, Vol. 248/3000). Lund: Lund University, Faculty of Engineering, Technology and Society, Traffic and Roads.

Madani, S., \& Diafat, A. (2010). Heritage and new community projects in the Mzab: case of Bani Isguen - Algeria. In Proceedings of the First International Conference for "Urban \& Architecture Heritage in Islamic Countries: Its role in Cultural \& Economic Development. Riyadh: The Saudi Commission for Tourism and Antiquities.

Madani, S., \& Diafat, A. (2016). Postcolonial urban changes of a colonial Village: case study of ain arnat - Algeria. In C. N. Silva (Ed.), Abingdon, urban planning in North Africa (chap 9, pp. 103-114). New York: Ashgate.

Mashary, A.-N. (2003). “Tafilelte Tajdite”, on-site Review Report, Ghardaia - Algeria; 2953 (pp. 23). Aga Khan. Retrieved in 2019, January 20, from

https://webcache.googleusercontent.com/search?q=cache:maQ5MWHI_ZIJ:https://docplayer.fr/108132491Tafilelte-tajdite-on-site-review-report-by-mashary-al-naim-ghardaia-algeria-2953-alg-architect-ahmed-nouhlocal-craftsmen.html $+\& \mathrm{~cd}=1 \& \mathrm{hl}=\mathrm{en} \& \mathrm{ct}=\mathrm{clnk} \& \mathrm{gl}=\mathrm{dz}$

Meadowcroft, J. (2000). Sustainable development: a new(ish) idea for a new century? Political Studies, 48(2), 370387. http://dx.doi.org/10.1111/1467-9248.00265.

Meliouh, F., \& Tabet, A. K. (2013). Vernacular versus social housing in the Algerian Sahara: women's quest for comfort. In Proceedings of the Zero Energy Mass Custom Home Conference. Miami: ZEMCH Network. Retrieved in 2019, January 28, from

https://www.researchgate.net/publication/274075136_VERNACULAR_VERSUS_SOCIAL_HOUSING_IN_THE_ALGE RIAN_SAHARA_WOMEN'S_QUEST_FOR_COMFORT

Messahel, M. B. (2011). Tafilalt, a community project to preserve the M'Zab Valley. In Proceedings of the European Network for Housing Research Conference 2011. Toulouse: European Network for Housing Research. Retrieved in 2019, January 27, from https://www.enhr.net/documents/2011France/WS09/Paper-MouniaBOUALI-MESSAHELWS09.pdf

Momtaz, R. I., \& Feisal, Z. (2012). Sustainable features of vernacular architecture: a case study of climatic controls in hot arid climate. In Proceedings of the XXXVIII International Association for Housing Science IAHS World Congress: vision for the future of housing: mega cities. Istanbul: Istanbul Technical University.

NetPosterWorks. (2013). Algeria. Retrieved in 2019, January 28, from

http://www.netposterworks.com/geography/africa/algeria-posters.html

Poncelet, B., Frigout, F., \& Auxent, B. (2005). Le projet européen septentrion: mutualiser les connaissances et les expériences. In Proceedings of the Patrimoine et projet urbain: interpréter la ville. Lille: CAUE du Nord.

Radberg, J. (1996). Towards a theory of sustainability and urban quality. In Proceedings of the IAPS 14: evolving environmental ideals. Stockholm: Royal Institute of Technology.

Ravereau, M. (2007) Architecture et climats, préserver l'exemple de l'architecture aboutie du M'zab pour s'en inspirer. In Proceedings of the Colloque international: la vallée du M'Zab, patrimoine mondial, face aux nouveaux enjeux et défis. Ghardaïa: OPVM.

Riphenburg, C. J. (2006). Mzab: home of desert puritans. Retrieved in 2019, January 28, from http://riphenbu.blogspot.com/2006/10/

Rouxel, F. (1999). L'héritage urbain et la ville de demain. Pour une approche de développement durable (28p.). Paris: METL Ministère de l'Equipement, des Transports, du Logement, du Tourisme et de la Mer.

Shah, A. (2008). Globalization, the information revolution, and emerging imperatives for rethinking fiscal federalism (pp. 75-104). USA: World Bank Group's. Retrieved in 2019, January 20, from

http://siteresources.worldbank.org/PSGLP/Resources/ShahGlobalizationtheinformationrevolutionandemergingi mperatives.pdf

Toffin, G. (1994). Ecology and anthropology of traditional dwellings. Traditional Dwellings and Settlements Review, $5(2), 9-20$. 
Wikisource. (1987). Brundtland report: chapter 2: towards sustainable development. World Commission on Environment and Development. Retrieved in 2019, January 20, from

https://en.wikisource.org/wiki/Brundtland_Report/Chapter_2._Towards_Sustainable_Development

Editors: Janaina Camile Pasqual Lofhagen and Christopher Hawkins.

Received: Apr. 23, 2019

Approved: May 03, 2019 